Revista de Ciencias Sociales - Número 69 (2016) - Páginas 53-89

El significado de Gustav Radbruch para el Derecho Penal Contemporáneo

\title{
EL SIGNIFICADO DE GUSTAV RADBRUCH PARA EL DERECHO PENAL CONTEMPORÁNEO
}

\author{
THE MEANING OF GUSTAV RADBRUCH \\ FOR MODERN CRIMINAL LAW
}

\author{
JOSÉ LUIS GUZMÁN DALBORA* \\ CIFDE-UV \\ joseluis.guzman@uv.cl
}

\section{Resumen}

Gustav Radbruch es más conocido por sus contribuciones a la Filosofía del Derecho que por sus aportes al Derecho penal. El artículo trata justamente de estos últimos. Destaca las intuiciones del autor en materia de la acción delictiva, la causalidad y la estructura tripartita de la teoría del delito, y se detiene en construcciones muy originales también, como el concepto de delincuente por convicción y la conmensuración graduada de la pena. Explica

\footnotetext{
* Profesor titular de Derecho penal y de Introducción a la Filosofía jurídica y moral en la Universidad de Valparaíso (Chile). Investigador responsable del Centro de Investigaciones de Filosofía del Derecho y Derecho penal (CIFDE) de la misma Universidad. Artículo recibido el 1 de diciembre de 2016 y aceptado el 28 de diciembre de 2016.

El texto reproduce y anota la relación del autor al Congreso Internacional «Gustav Radbruch: Jurist, Philosoph, Politiker, Humanist», realizado en el Centro de Latinoamérica de la Universidad de Heidelberg, Santiago de Chile, los días 13 a 15 de octubre de 2016.
}

Revista de Ciencias Sociales - Número 69 (2016) - Universidad de Valparáíso - ISSN 0716-7725-Valparaíso, Chile 
finalmente la flexibilización que propuso el último Radbruch al dualismo metodológico en la Ciencia del Derecho.

\section{Palabras clave} convicción.

Filosofía del Derecho. Dogmática penal. Teoría del delito. Autor por

Abstract

Gustav Radbruch is best known for his contributions to the Philosophy of Law than for his contributions to Criminal law. The article deals precisely with the last ones. It emphasizes the author's intuitions in the matter of the criminal action, the causality and the tripartite structure of the theory of the crime, and it stops too at very original constructions, such as the concept of offender by conviction and the graduated sentencing. Finally it explains the flexibility that the last Radbruch proposed to the methodological dualism in the Science of Law.

\section{Keywords}

Philosophiy of Law. Criminal dogmatics. Theory of crime. Author by conviction. Offender by conviction.

\section{De la obra penalista de Gustav Radbruch en general}

$\mathrm{Al}$ preparar hace algunos años el estudio introductorio de la traducción castellana de la monografía penal más importante de Gustav Radbruch (1879-1949), observamos que su obra es mucho menos conocida en el medio hispanohablante como penalista que como filósofo del Derecho ${ }^{1}$.

Pues bien, repasando la apreciación de sus escritos en el país natal, resulta que nuestra advertencia parece perfectamente aplicable a

1. Guzmán Dalbora y Fernández: «Estudio introductorio» de Gustav Radbruch,

El concepto de acción y su importancia para el sistema del Derecho penal, Editorial

B. de F., Montevideo-Buenos Aires, 2011. (traducción y notas de José Luis Guzmán Dalbora). Cfr. págs. 1-2.

Facultad de Derecho y Ciencias Sociales - Universidad de Valparaíso - Chile 
los juristas alemanes². Por lo demás, algunos de éstos se expresan de manera idéntica. En el primero de los dos volúmenes que recogen la mayoría de los escritos penales de Radbruch, que vienen a ser el séptimo y octavo de sus Obras completas, Monika Frommel consigna que en la conciencia pública el jurista de Lübeck es tenido más como Filósofo del Derecho que como dogmático criminalista ${ }^{3}$.

No obstante, si sus creaciones iusfilosóficas son más numerosas y, seguramente, de mayor proyección internacional, es también considerable, cuantitativa y cualitativamente, lo que él produjo en las disciplinas que se ocupan de delito y pena. De los veinte tomos que componen las Obras completas, cinco abarcan todos los saberes criminales: Dogmática penal, Política criminal, Derecho penitenciario, Historia del Derecho penal, Criminología ${ }^{4}$. $\mathrm{Al}$ aspecto numérico de los trabajos, revelador de una vocación científica que él nunca dejó de cultivar, se añade la originalidad en el enfoque de los asuntos que acometió a lo largo del tiempo, entre otros, la relación de causalidad, el concepto de acción, la estructura de la teoría del delito, la responsabilidad por el resultado, el concepto de culpabilidad, la psicología de sus formas, el delincuente por convicción, la tentativa, participación y el concurso de infracciones, la conmensuración de la pena, la pena de muerte y las

2. Por ejemplo, en una extensa relación bibliográfica sobre Radbruch preparada por Jan Schröder figuran sólo seis estudios (Jescheck, Arthur Kaufmann, Krämer, Noll, Eberhard Schmidt y Spendel) acerca de las ideas penales del autor, entre decenas dedicados a su filosofía jurídica, política y social. Véase Kleinheyer y Schröder: Deutsche und Europäische Juristen aus neun Jahrhunderten, C. F. Müller Verlag, Heidelberg, $4^{a}$ ed., 1996, cfr. págs. 345-346.

3. Véase Einleitung en Radbruch, Gustav: Gesamtausgabe, herausgegeben von Arthur Kaufmann, 20 vols., C. F. Müller Verlag, Heidelberg, t. VII, 1995, cfr. pág. 1.

4. RADBRUCH, Gesamtausgabe, cit., tomos VII y VIII (Strafrecht, a cargo de Monika Frommel y Arthur Kaufmann, respectivamente), 1995 y 1998; t. IX (Strafrechtsreform, cuidado por Rudolf Wassermann), 1992; t. X (Strafvollzug, ídem, por Heinz Müller-Dietz), 1994, y t. XI (Strafrechtsgeschichte, ídem, por Ulfrid Neumann), 2001. Los temas y observaciones penales reaparecen en los volúmenes sobre Feuerbach (VI), el Derecho comparado (XV) y las Biografías (XVI).

Revista de Ciencias Sociales - Número 69 (2016) - Universidad de Valparaíso - ISSN 0716-7725-Valparaíso, Chile 
privativas de la libertad, la amnistía, la rehabilitación del condenado y, en la Parte especial, los delitos de asesinato, exposición de niños, robo, aborto, contra la mano de obra y de alta traición ${ }^{5}$.

Radbruch se abstuvo de preparar una exposición general de la atroz materia ${ }^{6}$, del mismo modo que resistió a la tentación de escribir un «sistema» de Filosofía del Derecho ${ }^{7}$. Sabemos que debutó como investigador con ensayos penales y que los filosófico-jurídicos vendrían más tarde, en el último cuadrienio de su primera estancia en Heidelberg. Es más, la Dogmática penal, no la Política criminal ni la Historia del Derecho punitivo, domina la fase inicial de su quehacer universitario

5. Reducida a cifras, en la lista de escritos de Radbruch contamos algo más de ochenta libros, capítulos de libros, artículos, conferencias y discursos que tratan de asuntos penales, sin mencionar las cuantiosas recensiones de obras ajenas que muestran a un atento observador de la construcción del sistema conceptual de la Parte general del Derecho penal a principios del siglo XX (acción, causalidad, antijuridicidad y culpabilidad entendidas como componentes de la teoría general del Derecho). La relación de las obras la tomamos de Holger Otte, Gustav Radbruchs Kieler Jahre 19191926, Peter Lang, Frankfurt am Main-Bern, 1982, cfr. págs. 267-333. Por su parte, Rodríguez Molinero enumera ciento quince escritos penales de Radbruch, quien "era ante todo penalista”, en una relación que incluye también los estudios sobre el procedimiento penal. Véase Rodríguez Molinero, Marcelino: Gustavo Radbruch, penalista. En: Nieto Martín (coordinador), Homenaje al Dr: Marino Barbero Santos. «In memoriam», 2 vols., Ediciones de la Universidad de Castilla-La Mancha y Salamanca, Cuenca, 2001, t. I, págs. 579, 587 y 591 . Acerca de los méritos de Radbruch como recensor, Frommel, op. cit., cfr. pág. 1.

6. Es verdad que intervino en una brevísima Introducción al Derecho penal sobre la base de casos, pero elaborada por otro autor, a la que él se limitó a completar en materia de tentativa, participación y concursos. Cfr. Herbert Engelhard, Einführung in das Strafrecht an Hand von Rechtsfällen. Ergänzt und herausgegeben von G. Radbruch, Rausch, Heidelberg, 2a ed., 1948. Como libro de enseñanza, sorprende por su claridad y la forma concisa, amén de magistral, con que las explicaciones de Radbruch aferran el núcleo de los problemas examinados. Kaufmann, Arthur: Einleitung. En: Radbruch, Gesamtausgabe, cit., t. VIII, cfr. pág. 4.

7. En el sentido de un sistema cerrado según los estilos del Derecho natural o del positivismo jurídico, a cambio de lo cual "en su Filosofía jurídica comparece claramente un sistema abierto". En: Kaufmann y Hassemer (editores): Einführung in Rechtsphilosophie und Rechtstheorie der Gegenwart, C. F. Müller Juristischer Verlag, Heidelberg, 6a ed., 1994, pág. 114.

Facultad de Derecho y Ciencias Sociales - Universidad de Valparaíso - Chile 
en la hermosa ciudad que se levanta al borde de ambos márgenes del río Neckar. Sin embargo, tras esas investigaciones científicas estuvo siempre el ímpetu filosófico. Lo mismo cabe predicar de las contribuciones al Derecho penal comparado que preparó en aquella época ${ }^{8}$. De su orientación filosófica, que experimenta un giro decisivo en los años de joven investigador, se dirá lo indispensable al comentar las obras penalistas, porque éstas reciben en cada pasaje aquel sello; como apunta de nuevo Monika Frommel, "también el dogmático penalista Gustav Radbruch es en primera línea filósofo del Derecho" ". Esos fundamentos filosóficos, perfeccionados y profundizados durante su posterior quehacer como catedrático en Heidelberg, son asimismo perceptibles en las obras penales que él elabora de 1932 a 1945, cuando el gobierno nazi lo destituye de la cátedra y condena al exilio en su propio país.

Por cierto, toda construcción dogmática, desde la simple interpretación hasta la factura de un sistema científico, está condicionada por circunstancias de tiempo y lugar, ya que su objeto es el Derecho positivo vigente. Sólo que en el caso de Radbruch esta limitación epistemológica afecta a una parte, no al entero quehacer científico ${ }^{10}$. La sobrevida de la otra parte de su trabajo en la ciencia de delitos y penas, que ciertos puntos que él mostró o desarrolló conserven actualidad en la Dogmática penal, se debe precisamente al encadenamiento iusfilosófico, a su dependencia de doctrinas que en el campo penalista cabe proclamar con carácter absoluto.

Aquí es posible distinguir tres grupos de aportaciones. Algunas se incardinan en la historia de los conceptos criminalistas, donde

8. Jescheck, Hans-Heinrich: Gustav Radbruchs Beitrag zur Strafrechtsvergleichung. En: Gedächtnisschrift für Gustav Radbruch, herausgegeben von Arthur Kaufmann, Vandenhoeck \& Ruprecht, Göttingen, 1968, cfr. pág. 356.

9. $\quad$ Frommel: op. cit., pág. 2.

10. Eberhard Schmidt atribuye valor actual solamente a los estudios políticocriminales e histórico-punitivos del autor. Véase Schmidt, Eberhard: Gustav Radbruch als Kriminalist. En: Zeitschrift für die gesamte Strafrechtswissenschaft, Walter de Gruyter \& Co., Berlín, tomo 63, 1951, cfr. pág. 165. Opinamos que su juicio es muy estrecho. 
aparecen como eslabón indispensable de su ulterior configuración. Otras, en cambio, están vivísimas en la estructura de ese sistema parcial que llamamos teoría del delito y en los conceptos básicos de la conmensuración de la pena. En fin, hay todavía una contribución original, procedente de los últimos años de Radbruch, que invita a efectuar un cambio en la concepción de la interpretación de la ley penal, a partir de una flexibilización del dualismo metodológico que profesó el autor, acercando los planos en apariencia contrapuestos de realidad y valor.

Aunque en lo que sigue haremos un repaso de los tres grupos de contribuciones, probablemente la última sea la de más urgente consideración, atendido el normativismo que se ha enseñoreado de un influyente sector de la Dogmática penal.

\section{La causalidad, el concepto de acción y la estructura de la teoría del delito}

El año 1902 Gustav Radbruch se doctoró en Berlín con una tesis sobre la teoría de la causa adecuada, que había dirigido Franz von Liszt (1851-1919). El tema, que el autor acometió con brío filosófico, era tempestivo en esa sazón ${ }^{11}$. Conociendo los múltiples aspectos en que Liszt dejó huella en Radbruch como jurista, era de suponer que en este escrito el discípulo manifestase su preferencia por la comprensión de su maestro criminalista sobre la causalidad, a la que éste entendía como una forma del conocimiento humano, un criterio de ordenación de nuestras representaciones con arreglo al cual las representaciones precedentes, llamadas causas, determinan las sucesivas, los efectos, y

11. Die Lehre von der adäquaten Verursachung. Abhandlungen des Kriminalistischen Instituts an der Universität Berlin, Nueva serie, número 3, Berlín, 1902, que manejamos en la edición de la Gesamtausgabe, cit., t. VII, cit., págs. 7-74. Martínez Bretones, María: Gustav Radbruch. Vida y obra, Universidad Nacional Autónoma de México, México, $2^{\text {a }}$ ed., 2003, pág. 21, comenta que es “un trabajo que se mueve en zona fronteriza: entre la dogmática y la filosofía, entre las ciencias de la naturaleza y las de la cultura”. Por lo demás, hay confesión explícita de este resultado en la autobiografía de Radbruch, Der innere Weg. Aufriss meines Lebens, K.F. Verlag, Stuttgart, 1951, cfr. pág. 75.

Facultad de Derecho y Ciencias Sociales - Universidad de Valparaíso - Chile 
en que no es factible atribuir un valor diferente a las condiciones que contribuyeron a provocar el resultado ${ }^{12}$. Radbruch realiza un detallado análisis de las diversas versiones de la causa adecuada, teoría que, al contrario, distingue entre condición y causa, para argumentar su rechazo en favor de la doctrina de la equivalencia de las condiciones (conditio sine qua non). Sin embargo, al examinar el problema de los delitos calificados por el resultado, que existían en el antiguo Código penal alemán y menudean todavía en textos vigentes, se aparta del maestro e insinúa un camino propio. Para él, en tales situaciones la responsabilidad por el efecto más grave ligado causalmente a la acción básica, es imputable al agente sólo en la medida que corresponda al peligro específico que fundamenta el delito en cuestión ${ }^{13}$. Esta era una solución asombrosa para un problema no resuelto satisfactoriamente ${ }^{14}$, en la que se anuncia el nervio teleológico de que pronto hará gala Radbruch. En el fondo, la consideración del vínculo entre el resultado agravante y el peligro ingénito a la acción típica, suponía un punto de vista normativo, no ya sólo la simple causalidad en sentido naturalista, sino aquel aspecto de la causalidad recogido en cada figura legal. Nos encontramos, pues, ante una pieza de la que poco tiempo después será la teoría de la relevancia, uno de cuyos fundadores, Max Ludwig Müller, cita repetida y gustosamente la tesis de Radbruch ${ }^{15}$, y el elemento central de la

12. VON LISZT, Franz: Tratado de Derecho penal, 3 vols., Reus, Madrid, t. II, 1916. (Trad. de Luis Jiménez de Asúa y adiciones por Quintiliano Saldaña) Cfr. págs. 293 y 299.

13. En Radbruch, Gustav: Die Lehre von der adäquaten Verursachung, cit., cfr. págs. 58 y 59. En esta última cita un pensamiento semejante de Reinhard Frank, sobre cuya doctrina puede consultarse en castellano Jiménez de Asúa, Luis: Tratado de Derecho penal, 7 vols., Losada, Buenos Aires, 1ª ed., t. III, 1958, pág. 683.

14. Idéntico, Schmidt, op. cit., cfr. pág. 153.

15. LUDWIG MÜLLER, Max: La significación de la relación causal en el Derecho penal y en el de reparación de daños, Hammurabi, Buenos Aires, 2009. (traducción de Marcelo A. Sancinetti, en el volumen compilado por éste Causalidad, riesgo e imputación. 100 años de contribuciones críticas sobre imputación objetiva). Cfr. págs. 64, 67, 96, 101 y 102. En cambio, el gran arquitecto de la teoría de la relevancia,

Revista de Ciencias Sociales - Número 69 (2016) - Universidad de Valparáíso - ISSN 0716-7725-Valparaíso, Chile 
hodierna teoría de la imputación objetiva ${ }^{16}$. Por cierto, Radbruch no abandonará los delitos calificados por el resultado. En otra breve monografía de su juventud propone compatibilizarlos con el principio de culpabilidad mediante la exigencia de que el resultado más grave sea a lo menos previsible para el autor, que se convertirá en Derecho positivo recién el año $1953^{17}$.

La adhesión a Liszt y, no obstante, la valentía de emprender una ruta especulativa personal en los problemas dogmáticos reaparecen en el escrito de habilitación, de $1904^{18}$. El criminalista austro-húngaro había culminado una notable labor constructiva en la Dogmática penal, reduciendo a un riguroso orden sistemático el material positivo con la ayuda de conceptos de progresiva abstracción, a partir de los cuales se podía abarcar todos los conceptos del sistema mediante determinación de los más elevados y generales ${ }^{19}$. Fue de este modo como aflora su

Mezger, si bien maneja la monografía de Radbruch, no le nombra como precursor del requisito de la relevancia típica del curso causal, tal vez porque la noción de tipo tampoco había aparecido en 1902, sino un año después, con Beling. En: Tratado de Derecho penal, 2 vols., nueva edición, revisada y puesta al día por José Arturo Rodríguez Muñoz, Editorial Revista de Derecho Privado, Madrid, 1955, t. I, cfr. págs. 223, 234, 241, 242, 243 y 245.

16. Por más que su elaborador principal mencione a Mezger, no a Radbruch, como antecedente de la imputación objetiva. ROXIN, Claus: Derecho penal. Parte general, tomo I, Fundamentos. La estructura jurídica del delito, Cívitas, Madrid, 1997. (Trad. de la $2^{a}$ edición alemana por Diego-Manuel Luzón Peña, Miguel Díaz y García Conlledo, y Javier de Vicente Remesal). Cfr. págs. 361-362.

17. RADBRUCH, Gustav: Erfolgshaftung. En: Vergleichende Darstellung des deutschen und ausländischen Strafrechts, Allgemeiner Teil, 6 vols., Liebmann, Berlin, t. II, 1908, cfr. pág. 251, y JESCHECK, Hans-Heinrich: op. cit., pág. 359. La prohibición de la responsabilidad objetiva en los delitos agravados por el evento figura hoy en el parágrafo 18 del Código penal alemán, que requiere que el autor o partícipe incurran a lo menos en culpa respecto de aquél.

18. Los datos de la edición castellana quedaron indicados, supra, nota 1.

19. SCHMIDT, Eberhard: Einführung in die Geschichte der deutschen Strafrechtspflege, Vandenhoeck \& Ruprecht, Göttingen, $3^{\text {a }}$ ed., 1995, cfr. pág. 383.

Facultad de Derecho y Ciencias Sociales - Universidad de Valparaíso - Chile 
definición del delito con los elementos que lo constituyen, a saber, una acción antijurídica, culpable y amenazada con pena ${ }^{20}$. En esto, Liszt se atuvo a la metodología deductivo-clasificatoria de la segunda mitad del siglo XIX. La vinculación con la Jurisprudencia de los conceptos, o expresado de manera más precisa, con el Jhering del método históriconaturalista, merced al cual la mentalidad propia de las ciencias naturales penetró en el positivismo jurídico decimonono, se expresa, además, en otra faceta de Liszt como dogmático, a saber, su entendimiento del acto delictuoso como un proceso físico que consiste en la manifestación de voluntad que causa o no impide consciente, motivada y espontáneamente un resultado. En el aislamiento del primer elemento del delito no se podía introducir el contenido de la voluntad que impulsa el movimiento corpóreo llamado acción, y tanto menos valorar lo realizado u omitido a la luz de su significado normativo o social.

Pues bien, Radbruch desarrolla sus ideas al compás de estas representaciones, incluso en la revolucionaria conclusión, que alcanza en las últimas páginas del pliego de habilitación, de la imposibilidad de reunir en un concepto superior los de acción y omisión. Con todo, no siguió exactamente el sistema en que se había formado ${ }^{21}$. En efecto, repudia la tendencia constructiva de las Pandectas y el método históriconatural, divisa un orden en los elementos que componen el concepto de delito, atribuye una función unitaria o sistemática al término genérico — la acción - del concepto y afirma que la validez de la construcción de las proposiciones inducidas de las normas jurídicas yace en el sentimiento jurídico, en juicios de valor y actos de voluntad, convicciones íntimas sobre el Derecho justo. Estas ideas representaban discrepancias metodológicas de envergadura frente al maestro. Todavía mayor fue la duda del discípulo acerca de la aptitud de la comprensión causal pura de la acción para convertirse en género de todos los delitos. La conclusión

20. VON LISZT, Franz: Tratado de Derecho penal, vol. cit., cfr. págs. 252-254.

21. Como, en cambio, afirma SCHMIDHÄUSER, Ebehard: Sobre la sistemática de la teoría del delito. Un tema fundamental de Radbruch desde el punto de vista de la nueva dogmática penal, en la revista Nuevo pensamiento penal, de Buenos Aires, año 4, enero-marzo de 1975, número 5. (Trad. de Juan Bustos Ramírez) Cfr. pág. (33-46) 35.

Revista de Ciencias Sociales - Número 69 (2016) - Universidad de Valparáíso - ISSN 0716-7725-Valparaíso, Chile 
Radbruch en el problema de la omisión, que consiste en una respuesta negativa, dado que en ella no sería dable observar ninguna de las exigencias de la acción — voluntad, causalidad y resultado-, por lo cual se comporta a su respecto como la negación de una posición, disyuntiva irreductible a un concepto superior, no era tanto consecuencia obligada del método lógico-conceptual, sino vástago de la falencia del concepto naturalista en orden a adjuntar a la acción la hipótesis pasiva, que existe y se califica conforme a apreciaciones jurídicas.

El escrito sobre la acción y el sistema del Derecho penal pertenece la historia contemporánea de la teoría del delito, parecidamente al adelanto de imputación objetiva que bosqueja la tesis doctoral. Sin embargo, con los mismos derechos pudiera ser contado entre componentes medulares de la Dogmática del presente. Su vigencia se percibe en el desmembramiento de la teoría del delito en ordenaciones bipartitas o cuatripartitas ${ }^{22}$ y, sobre todo, en la propensión de no pocos criminalistas a iniciar el estudio de la infracción penal desde la tipicidad, con lo que la teoría jurídica del delito se transforma en otra de la imputación, yendo desde un objeto cognoscitivo (el delito y sus elementos), con las materias primas que lo constituyen, hacia un conjunto de categorías o formas del pensamiento jurídico (las categorías de imputación).

También este osado tránsito lo anticipó Radbruch, siquiera no con los alcances que pretenden los émulos de la metodología categorial. En efecto, sus relaciones personales en Heidelberg durante los primeros tres lustros del siglo XX lo hicieron asumir el dualismo kantiano de ser y deber ser, prohijar la distinción neokantiana de realidad y valor, y acoger la lógica de la corriente sudoccidental del neokantismo ${ }^{23}$. Ya en

22. O sea, dos teorías del delito, una para el comisivo y otra para el omisivo, o bien cuatro, para los delitos comisivos doloso y culposo, y por omisión dolosa o culposa. Poco antes de morir, Radbruch volverá sobre la duplicidad del sistema del Derecho penal, en el artículo Drei Strafrechtslehrbücher des 19. Jahrhunderts. En: Arthur Wegner (editor), Festschrift für Ernst Heinrich Rosenfeld zu seinem 80. Geburtstag am 14. August 1949, Walter de Gruyter, Berlin, 1949, págs. 24.

23. En el Estudio introductorio citado supra, nota 1 (cfr. página 20, texto y nota 35), recordamos las personalidades determinantes de este vuelco intelectual, Heinrich Levy, discípulo de Wilhelm Windelband, y Emil Lask, y que por la influencia

Facultad de Derecho y Ciencias Sociales - Universidad de Valparaíso - Chile 
una recensión publicada en 1905 Radbruch se dolió de la estrechez del campo visual de los sistemas deductivo y clasificatorio que lo guiaron en su libro del año anterior ${ }^{24}$. Pero recién en dos artículos muy posteriores, Idea y materia del Derecho (1923) y Sobre el sistema de la teoría del delito (1930), redondeará la epistemología neokantiana aplicada a las cuestiones penales y su sistema neoclásico del hecho punible $^{25}$. En el de 1923, sobre el que volveremos más adelante, hace definitivo abandono del concepto naturalista de la acción en pos de otro preformado mediante conceptos sociales, en suma, un concepto normativo. En el de 1930, que para Kaufmann representa la ruptura decisiva de Radbruch en la estructuración del delito ${ }^{26}$, éste se decanta por un sistema teleológico.

Explica allí que el sistema categorial, con su distinción de forma y materia, en que la primera determina la segunda, presenta el inconveniente de que en la reconstrucción del delito obliga a pasar por el concepto general de lo injusto y, en consecuencia, partir del concepto superior de todo injusto, el concepto de acción, desde el cual una precisión cada vez más fina permitiría esclarecer lo injusto punible, como en el viejo sistema deductivo-clasificatorio. Pero, para Radbruch, "el concepto pre-penal y, en general, pre-jurídico de la acción, no clasificado de antemano en el marco del tipo legal [...], no es apropiado para servir de piedra angular al sistema del Derecho penal ni como soporte de los restantes elementos del delito" ${ }^{27}$. Conocida su tendencia

del último Radbruch se empapó del dualismo metódico, así como de la distinción entre forma y materia en el Derecho, que son ingredientes esenciales de un sistema jurídico de tipo teleológico.

24. RADBRUCH, Gustav: Zeitschrift für die gesamte Strafrechtswissenschaft, cit., t. 25, 1905, cfr. pág. 256.

25. La pareja de artículos tiene versión castellana, el primero en Radbruch, Tres estudios de Filosofía del Derecho y una arenga para los jóvenes juristas, traducción, introducción y notas por José Luis Guzmán Dalbora, Editorial B. de F., MontevideoBuenos Aires, 2013, págs. 33-45, y el segundo en Radbruch, El concepto de acción y su importancia para el sistema del Derecho penal, cit., págs. 177-197.

26. Einleitung, en Radbruch, Gesamtausgabe, t. VIII, cit., cfr. pág. 9.

27. RADBRUCH, G: Sobre el sistema de la teoría del delito, cit., pág. 181.

Revista de Ciencias Sociales - Número 69 (2016) - Universidad de Valparáíso - ISSN 0716-7725-Valparáiso, Chile 
normativista, se explica la inclinación por un sistema teleológico, que ordena el delito según fines (los de la pena) y medios (los elementos positivos y negativos del delito). Esta vez, el concepto de lo injusto punible es derivado, no de lo injusto en general, sino del fin de la punición. Y dado que en un sistema de fines, o lo que es igual, de aspiraciones concretas de la voluntad humana, la diferencia específica del delito frente a lo antijurídico en general no radica en el concepto categorial de la punibilidad, porque la fija el concepto históricamente condicionado de la ley como única fuente inmediata de esta rama del Derecho, tampoco hay para extrañarse de que esta ordenación conceptual "escogerá precisamente la característica peculiar de lo injusto punible, o sea, el tipo, como punto de partida de la definición del delito" 28 .

Con esto, Radbruch traza claramente la organización trimembre de la teoría del delito formada por tipicidad, antijuridicidad y culpablidad, en la cual el acto es absorbido por la tipicidad como núcleo de las figuras legales. Pese a ello, el autor formula la significativa advertencia de que la tripartición existe sólo en el sistema visible y didáctico, porque en el sistema invisible o teórico los límites de estos elementos son fluidos, hasta el punto de que a menudo se yuxtaponen parcialmente. Esto vale para la relación entre tipicidad y antijuridicidad, por la existencia de elementos normativos en los tipos y elementos subjetivos en la antijuridicidad, para la relación de tipicidad y culpabilidad, a causa de elementos típicos subjetivos, y, en fin, para la relación de antijuridicidad y culpabilidad, desde el momento que en lo injusto puede haber componentes subjetivos y la culpabilidad se había convertido en el ínterin en un concepto normativo ${ }^{29}$. Sobre todo, en el sistema interno de la ciencia no se puede separar tajantemente los componentes descriptivos y normativos, del mismo modo que en el juicio por jurados es imposible establecer una distinción neta entre la quaestio facti y la quaestio juris. "Si un concepto prejurídico — dice- se erige en concepto jurídico, adquiere inevitablemente rasgos normativos, por más

28. Ídem, pág. 180.

29. Ídem, cfr. págs. 184 a 189.

Facultad de Derecho y Ciencias Sociales - Universidad de Valparaíso - Chile 
que en su origen tuviese un puro carácter descriptivo [...], no es capaz de substraerse a la transformación normativa que le imprime una interpretación teleológica" ${ }^{30}$. Más adelante comprobaremos cómo Radbruch templó este vuelo normativista, armonizándolo mejor con la metodología teleológica que él consiguió instalar en el corazón de la Dogmática punitiva, y por qué esta enseñanza postrema del autor debiera ser tomada especialmente en cuenta por quienes cultivamos la ciencia de delitos y penas.

\section{La posición sistemática de la imputabilidad y la naturaleza de la culpabilidad}

A principios del siglo XX imperaba aún, aunque con sus días contados, la vetusta concepción psicológica de la culpabilidad. Con arreglo a ella, este elemento del delito consiste en una relación psíquica de conocimiento y voluntad entre el autor y el resultado delictuoso. Por consiguiente, dolo y culpa son hechos mentales que existen o faltan, pero no pueden darse en más o en menos, del mismo modo que tampoco sería susceptible de graduación la imputabilidad, que según dicha teoría era un presupuesto subjetivo de la culpabilidad.

Ya en el escrito de habilitación Radbruch expuso su disenso de tal emplazamiento de la imputabilidad. A decir verdad, ésta había recorrido un incierto periplo a lo largo de la centuria precedente, cuyo penalismo la estimó primero capacidad de pena, luego capacidad de acción o capacidad de infringir deberes jurídicos, hasta asignarle el papel de presupuesto o componente de la culpabilidad ${ }^{31}$. Radbruch se subleva contra esta manera de ver, aduciendo dos argumentos: uno lógico, el de

30. Ídem, pág. 189.

31. Para Franz von Liszt, la imputación contenida en el juicio de culpabilidad constaría de dos elementos, la imputabilidad del autor (la facultad del agente de determinarse de modo normal) y la imputación del acto (el dolo o la culpa). Véase op. et vol. cits., págs. 376 y 377. La trayectoria de la imputabilidad en el sistema de la teoría del delito (y en la del reo, para un Derecho penal tripartito) es minuciosamente documentada por Jiménez de Asúa, op. cit., t. V, 1956, págs. 81-86, y Frías Caballero. En: Capacidad de culpabilidad penal, Hammurabi, Buenos Aires, 1994, págs. 25-43.

Revista de Ciencias Sociales - Número 69 (2016) - Universidad de Valparáíso - ISSN 0716-7725-Valparáiso, Chile 
que si la imputabilidad es capacidad de culpabilidad, se torna ipso facto un concepto superfluo, pues carece de sentido establecer la posibilidad de la inculpación cuando de todos modos hay que determinar la realidad de la inculpación; y psicológico el otro, porque también en los inimputables puede presentarse una conducta dolosa o culposa. En su opinión, que fue asimismo la de Feuerbach, Bauer, Geib y Luden, entre otros autores decimononos, la imputabilidad es presupuesto, no de la atribución al dolo y a la culpa, sino del dolo y de la culpa, en otras palabras, capacidad de pena ${ }^{32}$. En la conferencia de habilitación, que quedó documentada en un artículo de 1904, Radbruch se extiende sobre las ventajas de devolver la imputabilidad al sitio de aptitud subjetiva de la penalidad, una de las cuales es que así deviene hacedero graduar cuantitativamente la imputabilidad y cualitativamente la pena ${ }^{33}$. En 1930 reafirma que la imputabilidad no es una formación conceptual unitaria, la doli vel culpae capacitas de las Pandectas. Una metodología teleológica hará tesoro de la información psicológica de que los sujetos pueden ser inimputables por muy diferentes razones, pese a lo cual en ninguno de estos casos el juez está autorizado para irrogar una pena ${ }^{34}$.

Causa extrañeza que la Dogmática, deslumbrada por la concepción normativa de la culpabilidad, continúe apegada a la consideración categorial de la imputabilidad, cuya riqueza de pormenores — biológicos, psíquicos, psiquiátricos, caracterológicoses así aplastada bajo la lápida de la capacidad de culpabilidad o como un elemento de ésta ${ }^{35}$. En cambio, el modo de pensar el Derecho de Radbruch, criminalista atentísimo al secreto comercio que circula entre

32. RADBRUCH, Gustav: El concepto de acción y su importancia para el sistema del Derecho penal, cit., cfr. págs. 128 y 129.

33. Über den Schuldbegriff, artículo aparecido originalmente en Zeitschrift für die gesamte Strafrechtswissenschaft, cit., t. 24, 1904, págs. 333-348, y recopilado en la Gesamtausgabe, cit., t. VII, cit., págs. 207-219, cfr. págs. 215-216.

34. RADBRUCH, G.: Sobre el sistema de la teoría del delito, cit., cfr. pág. 193.

35. Véase, por todos, Jescheck y Weigend, Lehrbuch des Strafrechts. Allgemeiner Teil, Duncker \& Humblot, Berlín, $5^{\mathrm{a}}$ ed., 1996, pág. 433.

Facultad de Derecho y Ciencias Sociales - Universidad de Valparaíso - Chile 
los fundamentos filosóficos y las raíces empíricas de la teoría del delito, provee herramientas apropiadas para enfrentar graves problemas con que nuestro tiempo desafía a juristas y legisladores. Por ejemplo, si la imputabilidad es capacidad subjetiva de pena, se hallará una solución científica para el llamado error de comprensión culturalmente condicionado que no degrada la entidad humana de las personas pertenecientes a una unidad cultural autóctona — como las numerosas comunidades indígenas que pueblan Iberoamérica - o transferidas al territorio de una cultura ajena - pensemos esta vez en el Derecho que traen consigo los africanos y asiáticos establecidos en Europa y Norteamérica-; también se podrá encarar con responsabilidad política el reto de la sociedad multicultural, que exige limitaciones personales en la esfera de validez de la ley penal del Estado dominante o receptor ${ }^{36}$.

Radbruch permaneció fiel hasta el final de sus días a la teoría psicológica de la culpabilidad. No obstante, en el artículo de 1904 se preguntó por la factibilidad de reconducir dolo y culpa a un concepto superior unificador. La sola formulación de la inquietud era un anticipo de la teoría normativa, cuyas bondades él reconocerá en su momento aunque sin hacer abandono del substrato psíquico de la culpabilidad. El concepto genérico era de imposible consecución al socaire del puro psicologismo. Sin embargo, en el afán de depurar la culpabilidad de cuerpos extraños, Radbruch consigue dos descubrimientos. Uno, muy citado, es lo inconciliable de la culpa inconsciente con el entendimiento psicológico de la culpa. Al otro, menos conocido, llegó gracias a una asociación de los delitos culposos con los comisivos por omisión. Si en éstos hay una doble antijuridicidad, referida al resultado en sí y a la abstención de la acción que lo hubiera evitado, los delitos culposos se les parecen por la omisión antijurídica de la tensión de la voluntad o, expresado positivamente, la insuficiente atención o cautela que desencadenó el resultado. Por lo mismo, "la exigencia de un grado de

36. Acerca de todo lo cual nos explayamos en el artículo Derecho penal y minorías étnicas: planteamiento y liquidación criminalista de un problema político, en la Revista de Derecho penal y Criminología, de Buenos Aires, La Ley, año III, número 7, agosto de 2013, págs. 243-257, incluido también en el volumen Derecho penal y Constitución, compilado por Fernando Velásquez Velásquez y Renato Vargas Lozano, Universidad Sergio Arboleda, Bogotá, 2014, págs. 131-155.

Revista de Ciencias Sociales - Número 69 (2016) - Universidad de Valparáíso - ISSN 0716-7725-Valparáiso, Chile 
imprevisión superior al normal es un elemento, no de la culpa, sino de la antijuridicidad de la acción culposa, de suerte que en el concepto de culpa resta sólo el requisito de la no previsión imprudente del resultado previsible" ${ }^{37}$. La crítica posterior acierta en que así no se hubiera llegado jamás a la unificación de dolo y culpa ${ }^{38}$, pero pasa por alto que Radbruch dio con el correcto enclave del deber objetivo de cuidado mucho antes que otros lo vislumbraran en la antijuridicidad ${ }^{39}$.

En 1928 y 1930 el jurista hanseático vuelve a confrontarse con la culpabilidad. Denuncia que los tipos del dolo y de la culpa son fijaciones toscas de un contenido psicológico sumamente complejo, productos momificados de una psicología primitiva, como quiera que aíslan nada más que la representación del hecho y, por el contrario, desprecian el carácter del sujeto agente, en circunstancias que dolo y culpa debieran tener en común el reproche por la indiferencia del autor, su carencia de aquella medida de sentimiento valorativo indispensable para la preservación de los bienes protegidos por el Derecho, la incapacidad de sentir como propio el sufrimiento ajeno, en suma, una cuestión de falta de fantasía ${ }^{40}$. El trabajo de 1928 es una presentación breve, pero

37. Über den Schuldbegriff, cit., pág. 219.

38. Jiménez de Asúa: op. cit., t. V, cfr. págs. 287-288.

39. No peca de esta desatención Corcoy Bidasolo: El delito imprudente. Criterios de imputación del resultado, Editorial B. de F., Montevideo-Buenos Aires, 2005, págs. 20-70, en su repaso de los próceres de la bipartición del deber de cuidado, el general en la antijuridicidad, el individual en la culpabilidad. En páginas 34-35 se ocupa del paralelismo de Radbruch, y reconoce la dificultad de deslindar los deberes de cuidado y deberes de garante.

40. Zur Psycologie der strafrechlichen Schuldformen, recopilado en Gesamtausgabe, cit., t. VIII, cit., págs. 184-189. La Phantasielosigkeit es la explicación que Radbruch brinda en sus obras históricas para ilustrar las etapas de inaudita crueldad del sistema penal. En este artículo es presentada como la raíz del pretexto de aquellos criminales que, sabiéndolo, aducen que no sabían lo que hacían. Acerca de la falta de fantasía y su vínculo con el auge de los castigos corporales, particularmente la pena de muerte. Véase Radbruch: Ars moriendi, en su libro Elegantiae Juris Criminalis, Verlag für Recht und Gesellschaft AG., Basel, 2a ed., 1950, cfr. pág. 173, y De la pena de muerte, en la Revista de Derecho Penal y Criminología, de Buenos Aires, cit., año IV, número 1, febrero de 2014. (Trad. de José Luis Guzmán Dalbora), pág. 252.

Facultad de Derecho y Ciencias Sociales - Universidad de Valparaíso - Chile 
fascinante y demostrativa de cómo el genio de Radbruch lograba identificar espinosísimos problemas jurídicos aprovechando las conexiones extra-jurídicas de que está formada su base normativa. Sin embargo, ni allí como tampoco en el artículo de dos años después, podemos secundarlo en la solución de atribuir la culpabilidad por el delito a la personalidad o el carácter del sujeto actuante. Desde el punto de vista psicológico puede ser correcto que el proceso cognoscitivo deba ir, "no del hecho a la personalidad, sino de la personalidad al hecho"41; pero, desde el punto de vista jurídico y político, esto significaría el derrumbe del principio de legalidad, una inadmisible invasión de la intimidad de los justiciables y el eclipse de la trabajosa distinción de Derecho y moral ${ }^{42}$.

\section{El autor por convicción}

El autor por convicción fue una creación teórica y, a la vez, una concreta propuesta legislativa de Radbruch en la República de Weimar, cuando ocupó el cargo de Ministro de Justicia. Esto no quiere decir, empero, que el concepto surgió abruptamente del ingenio político del titular de la cartera. Muy por el contrario, enraizaba en hondas concepciones metafísico-jurídicas, axiológicas, políticas y sociales suyas.

Por lo pronto, en la Filosofía del Derecho él adhirió a una teoría histórico-sociológica acerca del fundamento de validez de las normas jurídicas, la teoría del reconocimiento, con arreglo a la cual la validez del Derecho positivo descansa en la conformidad de los sometidos a él, quienes lo reconocen a través de su comportamiento observante. Ahora, como para Radbruch este reconocimiento es función, no de la voluntad,

41. RADBRUCH, Gustav: Zur Psycologie der strafrechlichen Schuldformen, cit., pág. 188. De la imputación al carácter trata el artículo Sobre el sistema de la teoría del delito, cit., cfr. págs. 190-191.

42. Hemos examinado y criticado las teorías de la culpabilidad por la personalidad o el carácter en nuestro Estudio preliminar a la obra de Engisch, Karl: La teoría de la libertad de la voluntad en la actual doctrina filosófica del Derecho penal. Editorial B. de F., Montevideo-Buenos Aires, 2006, publicado también por Edeval (colección «Juristas perennes», número 11), Valparaíso, 2006.

Revista de Ciencias Sociales - Número 69 (2016) - Universidad de Valparáíso - ISSN 0716-7725-Valparaíso, Chile 
sino del sentimiento, se yergue victorioso contra la objeción de que fallaría precisamente allí donde más debiera mostrar su fuerza, frente al delincuente. El delincuente común — dice_- "no se sacude sin más el sentimiento jurídico que le une a la norma, por el hecho de la transgresión de ésta"; antes bien, el ladrón reconoce la propiedad que pretende antijurídicamente para sí, del mismo modo que el falsario cree tanto en la fe pública, que la quiere asimismo para el documento que falsifica. En otras palabras, por lo general los criminales reconocen el bien jurídico que han violado y, en consecuencia, también la protección jurídica que contra ellos mismos se aplica ${ }^{43}$. La teoría del reconocimiento, que en el fondo desciende de la doctrina del contrato social en el papel de fundamento general del imperio del Derecho, considera legítimo penar a un individuo que está en contradicción consigo mismo, como es el delincuente común, pero halla dificultades en el delito cometido por una convicción política, religiosa o moral, porque su autor no está en contradicción consigo mismo ni es refutable desde sí. Al contrario, actúa persuadido de un deber inscrito en una concepción opuesta al ordenamiento jurídico, piensa de otra manera y, por ende, carece de sentido oponerle una pena fundada en la superioridad moral o política del Estado que castiga, previene o corrige voluntades mal inclinadas. Frente al autor por convicción procedería la pena estatal entendida solamente como una "defensa propia contra el enemigo interno, como una especie de prisión de guerra en una guerra interior" ${ }^{44}$.

Por otra parte, en la esfera axiológica Radbruch asumió una postura relativista. La característica del relativismo es la validez

43. RADBRUCH, Gustav: Filosofía del Derecho, Editorial Revista de Derecho Privado, Madrid, $3^{a}$ ed., 1952. (Trad. de José Medina Echavarría) Cfr. pág. 107.

44. RADBRUCH, Gustav: La idea educativa en el Derecho penal, en su libro El hombre en el Derecho. Conferencias y artículos seleccionados sobre cuestiones fundamentales del Derecho, traducción de Aníbal del Campo, Depalma, Buenos Aires, 1980, pág. 64. Antes había formulado el mismo pensamiento en el segundo artículo que escribió sobre el tema, Der Überzeugungsverbrecher (1926), recopilado en Gesamtausgabe, cit., t. VIII, cit., cfr. pág. 131.

Facultad de Derecho y Ciencias Sociales - Universidad de Valparaíso - Chile 
condicional de los valores. Dado que todo valor relativo es cultural, el relativismo nos ofrece el panorama de una miríada de valores que pretenden simultáneamente validez, pese a ser en parte compatibles y en parte antagónicos. Pero la imposibilidad de comprobar científicamente la verdad de las distintas concepciones axiológicas, ante las cuales sólo cabe tomar una decisión, no equivale a que el relativismo tenga que resignar toda aspiración intemporal, que haya de sumirse en el escepticismo. La propia posibilidad de la coexistencia de concepciones diferentes tiene como supuesto la igualdad esencial de los hombres y, de suyo, la tolerancia entre ellos. De ahí que "el relativismo puede tolerar toda opinión, fuera de aquella que sostiene ser absoluta" y se arroga el derecho de aniquilar a las demás; "relativismo es tolerancia, en general, menos con respecto a la intolerancia" ${ }^{45}$.

Este sistema axiológico se proyecta en una determinada concepción del Derecho y en la ideología política correlativa. Desenlace jurídico del relativismo es una teoría individualista que pone el Derecho y el Estado al servicio de la persona. Patentiza su esencia en la figura del contrato y postula como idea del Derecho la seguridad jurídica. El individualismo, al contemplar el Derecho como relaciones entre personas, imagina al Estado cual fruto de un contrato, del que afirma, no que los Estados reales tengan que haberse originado en él, sino que el Estado es tal sólo si puede ser pensado, en cada uno de sus momentos, como nacido de un acuerdo libremente contraído entre sus miembros, cuando cada una de sus disposiciones jurídicas puede ser considerada como existente en interés de los individuos. A su vez, en lo político el relativismo desemboca en el liberalismo, en la persuasión de "que el contenido de verdad de las distintas convicciones políticas y sociales no es científicamente reconocible, y que por consiguiente debe considerarse a todas estas convicciones como dotadas de igual valor" ${ }^{\text {"4 }}$.

45. RADBRUCH, Gustav: El relativismo en la Filosofía del Derecho, en El hombre en el Derecho, cit., pág. 101 (con cursivas en el original). La pena del delincuente por convicción, que éste ha de soportar, no como un deber, sino cual una coerción, está íntimamente asociada al relativismo de Radbruch, a su tolerancia y su sentido de la humanidad, escribe Baratta, Alessandro: Relativismus und Naturrecht im Denken Gustav Radbruchs, en ídem, Philosophie und Strafrecht. Aufgewählte Aufsätze 19591974, Carl Heymanns Verlag, Köln-Berlin-Bonn-München, 1985, págs. 1-29, cfr. pág. 13.

46. Ídem, págs. 98 y 99.

Revista de Ciencias Sociales - Número 69 (2016) - Universidad de Valparaíso - ISSN 0716-7725-Valparaíso, Chile 
Finalmente, Radbruch fue un decidido partidario de la justicia social, entendiendo por ésta una imagen de la sociedad en que el hombre no es una abstracción descarnada, incolora, libre de los múltiples condicionamientos que forman la personalidad y delimitan las posibilidades de actuación, sino un espejo que lo retrata en su concreta posición o, a lo menos, dentro de la tipología humana en que esos mismos condicionamientos incardinan a los sujetos. La prevención especial positiva, penar al delincuente con fines de corrección individual, que Radbruch aprendió de su maestro Franz von Liszt, se adecuaba perfectamente a esta manera de ver, que hace tesoro de las circunstancias personales y sociales del hecho delictuoso ${ }^{47}$.

En la metodología teleológica de Radbruch las finalidades retributiva, preventivo-general y preventivo-especial tenían que fracasar ante el tipo humano del delincuente por convicción. El Proyecto de Código penal general alemán que él preparó en 1922 lo caracteriza así: "Si el móvil preponderante del autor residió en que él se creyó obligado a realizar el hecho a causa de sus convicciones morales, religiosas o políticas, prisión rigurosa y prisión simple serán reemplazadas por el encierro de la misma duración" (artículo 71) ${ }^{48}$. Aparte de la originalidad de la denominación, con su concepto Radbruch concedió un alcance mayor a la discusión iniciada en el siglo XIX en torno del delincuente político. Por cierto, delito político y delito por convicción son conceptos parcialmente yuxtapuestos, porque el agente que obra por motivación política representa una clase del delincuente por convicción ${ }^{49}$. Su vínculo se aprecia en el criterio que empleó Radbruch para aislar el segundo concepto, no ya la objetividad jurídica del delito, sino la motivación del autor, a semejanza de la propuesta de Enrico Ferri respecto los

47. SCHMIDT, Gustav Radbruch als Kriminalist, cit., cfr. pág. 158.

48. RADBRUCH, Gustav: "El delincuente por convicción” en Revista Electrónica de Ciencia penal y Criminología, de Granada (España), 2005, número 7, disponible en internet http://criminet.ugr.es/recpc/07/repc07-r4.pdf, (traducción y notas de José Luis Guzmán Dalbora ) pág. 2. Este artículo, el primero sobre el argumento, se conoció en 1924.

49. JIMÉNEZ DE ASÚA, Tratado de Derecho penal, cit., t. III, cfr. pág. 244.

Facultad de Derecho y Ciencias Sociales - Universidad de Valparaíso - Chile 
delincuentes político-sociales en su Proyecto de Código penal para Italia de $1921^{50}$. Frente a este tipo psicológico-criminal de contornos nítidos, que lo realzan y distinguen del delincuente común, la pena retributiva queda vacía de fundamento, ya que el delincuente por convicción no reconoce superioridad moral al Estado que lo pune y nunca experimentará un sentimiento de culpabilidad. La prevención general mediante la intimidación se transforma en su opuesto, porque la experiencia enseña que la pena intimidatoria convierte al convicto en mártir, colabora paradójicamente con su causa. Y de la prevención especial en el autor por convicción, ni hablar: "tal vez quepa convencerlo de algo mejor, pero pretender «mejorarle», eso nunca jamás" ${ }^{51}$. Para estos hechores la pena debía consistir nada más que en apartarlos del ruedo de las pugnas políticas, como una suerte de prisión militar, hasta que se tornen inocuos merced al cambio de la situación del país, mejor aún, en "una medida de seguridad, una medida de defensa o de lucha del Estado contra los adversarios de las circunstancias presentes" ${ }^{2}$. En lo cual no debe verse que el Estado incurre en una negación de sí mismo, sino más bien la actitud resignada que corresponde a la esencia del Estado democrático ${ }^{53}$.

50. El propio Radbruch reconoció públicamente, en su alocución al Congreso de los Juristas Alemanes realizado en Colonia en 1926, que las fuentes de su idea habrían sido el Derecho penal francés y el Proyecto de Ferri. De hecho, tomó de ellos un régimen penal diferenciado para los autores por convicción y la concepción ferriana de tratarse de una tipología especial de delincuentes, definida por una motivación evolutiva, no atávica o regresiva. Sin embargo, extiende el concepto a las motivaciones religiosas y morales, aparte de que no exige que el sujeto haya obrado "exclusivamente por motivos políticos o de interés colectivo", como se lee en el artículo 13 del Proyecto de Ferri. Radbruch, Gustav: Über die Frage vom Überzengungsverbrecher, en Gesamtausgabe, cit., t. VIII, cit., cfr. págs. 138, 145, 146 y 147, y Ferri, Enrico: Proyecto preliminar de Código penal para Italia, Centro Editorial de Góngora, Madrid, 1925. (Trad. y estudio por Cristino Jiménez Escribano, epílogo de Quintiliano Saldaña) Págs. 77-80, 108, 120-121 y 126.

51. RADBRUCH: El delincuente por convicción, cit., pág. 3, y Über die Frage vom Überzeugungsverbrecher, cit., cfr. págs. 141-142.

52. $\quad$ Über die Frage vom Überzeugungsverbrecher, cit., pág. 143.

53. "El Estado democrático no está edificado sobre la asunción de una verdad política demostrable y unívoca; conoce sólo opiniones mayoritarias y minoritarias acerca de verdades políticas nunca susceptibles de demostración inequívoca”. Ibídem.

Revista de Ciencias Sociales - Número 69 (2016) - Universidad de Valparáíso - ISSN 0716-7725-Valparáiso, Chile 
El Proyecto de Radbruch se frustró a causa del mismo clima de violencia política en que fue elaborado, prueba ulterior de la valentía de su autor al presentar estas avanzadísimas ideas ${ }^{54}$ Andando los años, el manejo unitario de la delincuencia por convicción, basado en que todas las concepciones políticas y existenciales demandan una consecuencia jurídica no discriminatoria, cedió el paso a la diferenciación de autores por motivos de conciencia y autores por convicción en sentido estricto. El afinamiento de los conceptos dogmáticos, a la par de la creciente lectura constitucional e internacional de los preceptos penales, permitieron reconocer una causa de justificación, el ejercicio legítimo del derecho fundamental de la libertad de conciencia, a una parte de las situaciones nombradas en primer lugar, mientras que la responsabilidad penal de la autoría por convicción es aún materia de controversia y uno de los capítulos más delicados de la doctrina de la culpabilidad en la teoría del delito ${ }^{55}$. En verdad, sigue por debajo el gigante con que lidió Radbruch la mentalidad unidimensional que descalifica toda forma de disidencia al ajuste del poder económico, social y político, cuya natural tendencia en nuestros días consiste en rotular como enemigos o terroristas a los adversarios que precipitan criminalmente la consecución de sus afanes. Acaso haya que asumir que las circunstancias del momento aconsejarían tratar al terrorista al revés de como planteó Radbruch. No que el Estado, en nombre de una supuesta razón y ética propias, haga el juego al fanatismo difamando y empleando métodos inhumanos contra quien piensa diferente ${ }^{56}$, sino

54. Decisivo parece haber sido el asesinato del Ministro de Asuntos Exteriores Walter Rathenau en junio de 1922, cuando el Proyecto estaba casi pronto en su Parte general y Radbruch confiaba que fuese llevado al Parlamento y aprobado antes de las elecciones de 1924. En: Der innere Weg. Aufriss meines Lebens, cit., cfr. págs. 156-157. Acerca de la violencia política que asoló a la República de Weimar, permanentemente amenazada por extremistas de derecha, véase Weitz, Eric: La Alemania de Weimar. Presagio y tragedia, Turner, Madrid, 2009. (Traducción de Gregorio Cantera). Págs. 102-123.

55. HIRSCH, Hans: Derecho penal y autor por convicción, traducción de Patricia Laurenzo Copello, en sus Obras completas, 5 vols., Rubinzal-Culzoni Editores, Buenos Aires, t. II, 2000, cfr. págs. 171-207.

56. Cual practicó el nacionalsocialismo a partir de 1933, como observa Schmidt: en Gustav Radbruch als Kriminalist, cit., cfr. pág. 163, donde explica por qué

Facultad de Derecho y Ciencias Sociales - Universidad de Valparaíso - Chile 
devolver a los acusados de terrorismo al terreno de la delincuencia común ${ }^{57}$.

\section{La conmensuración de la pena}

También en la conmensuración de la pena Radbruch se adelantó a su época y esbozó medios con que abordar la complicación más ardua del asunto, que consiste en cómo concretar judicialmente la penalidad.

Ya en un temprano trabajo acerca de la adaptación legal de la pena $^{58}$ se había confrontado con dos dilemas generales de política criminal, si hay que optar por la graduación judicial o legal de la pena y, por otra parte, si convienen márgenes penales estrechos o amplios en los delitos de la Parte especial. El estudio impresiona por la clasificación de los factores generales y especiales de atenuación de la responsabilidad criminal, en los que declara de lege ferenda su preferencia por las circunstancias atenuantes comunes de la legislación francesa, el razonamiento de la compatibilidad entre la mayoría de los factores atenuantes, con el correspondiente concurso homogéneo (o acumulación, en la terminología germánica), el recelo por la compatibilidad de las atenuantes y la reincidencia, y, en fin, la crítica de la reincidencia en función agravante, pues su fundamento en la ineficacia de la pena ya sufrida parece vano mientras del ideal de la corrección individual en la ejecución y la asistencia post penitenciaria no se cumplan cabalmente en la realidad ${ }^{59}$. Sin embargo, lo más interesante del trabajo de 1908 nos sale al paso en

la idea de Radbruch, con su tendencia hacia la humanización de la jurisdicción penal, puede ser un modelo ideal, pero no una irrealizable ilusión.

57. Hemos razonado detenidamente este punto de vista en Guzmán Dalbora: El terrorismo como delito común, en el volumen Terrorismo y Derecho penal, editado por Kai Ambos, Ezequiel Malarino y Christian Steiner, Konrad-Adenauer-Stiftung, Montevideo, 2015, págs. 401-437.

58. Die gesetzliche Strafänderung, en Vergleichende Darstellung des deutschen und ausländischen Strafrechts, Allgemeiner Teil, cit., t. III, 1908, págs. 189-219.

59. Ídem, cfr. pág. 211. La influencia de Liszt es patente en esto. Además, Jescheck, cfr. op. cit., pág. 359.

Revista de Ciencias Sociales - Número 69 (2016) - Universidad de Valparáíso - ISSN 0716-7725-Valparáiso, Chile 
la formulación inicial del dilema arbitrio judicial o vinculación legal en la aplicación de las puniciones. Radbruch percibe un conflicto entre dos ideas del Derecho, seguridad jurídica y justicia, vista la generalización inherente a la seguridad y la especialización distintiva de la justicia. Por eso, lo que se gana en seguridad merced al establecimiento de márgenes penales netos, es perdido para la justicia en su anhelo de reflejar en la pena la gravedad exacta del delito. Incluso la ganancia en seguridad puede ser dudosa, piensa nuestro autor. Si se pone límites estrechos al arbitrio judicial en la cuestión de la pena, él se cobrará revancha de la libertad perdida arrogándosela en la ponderación de la culpabilidad, ya que cada límite de la pena será fuente de disputas en la estimación de los elementos graduables del delito. Así, "cuantos más límites, tantos más serán los casos fronterizos; mientras más casos fronterizos, mayores controversias; cuantas más controversias, tanto mayor será la inseguridad jurídica" ${ }^{60}$.

Veinte años después Radbruch señalará una forma con que desatar este nudo gordiano desde la filosofía jurídica. Para ello, era indispensable ampliar el arsenal de herramientas de la Dogmática penal, ligada hasta ese punto a un elemento de la lógica tradicional, los conceptos de clasificación. Los conceptos de clasificación definen o delimitan, responden a la disyuntiva «si o no». Por consiguiente, su valor en la concreción de las penas reside en los factores que el juez debe tomar en cuenta para fijar la magnitud de la que correspondería a un delito, dado que tales factores se presentarán o no en el caso bajo enjuiciamiento. Sin embargo, dejan al juez en la indigencia acerca del fundamento de esta operación y, sobre todo, nada le dicen del grado en que cada uno de los factores puede incidir en el monto la pena. La adición de los conceptos ordenadores a los de clasificación, objeto del extraordinario estudio de 1938, intenta responder a entrambos interrogantes ${ }^{61}$. Estos conceptos son tipológicos o funcionales; no aprietan

60. Ídem, cfr. pág. 189. De ahí también que se inclinase por las circunstancias generales de atenuación, para evitar la práctica de los tribunales, sea de imponer penas muy cercanas al mínimo legal, sea de castigar con la misma pena aplicable a casos de gravedad promedio, otros de entidad extraordinariamente leve cuando la única penalidad disponible posee márgenes muy dilatados entre sí (cfr. pág. 199).

61. Conceptos de clasificación y conceptos ordenadores en el pensamiento jurídico, en Radbruch: El concepto de acción y su importancia para el sistema del Derecho penal, cit., págs. 199-214.

Facultad de Derecho y Ciencias Sociales - Universidad de Valparaíso - Chile 
con un corsé predefinido la realidad, sino que permiten graduarla y compararla según la fórmula «cuanto más (o cuanto menos), tanto más (o tanto menos)». Radbruch exaltó sus ventajas para la concreción de la pena. La cantidad precisa de ésta depende de la extensión de lo injusto y la medida de la culpabilidad; allí reside el fundamento de la conmensuración judicial. Pero esto presupone que antijuridicidad y culpabilidad no son conceptos puros de clasificación, como en la teoría del delito del sistema clasificatorio, sino que, al revés, pueden darse en más o en menos. Pues bien, de cada uno de los factores de concreción deriva un orden progresivo, y en cada uno de éstos habrá que asignar el valor que corresponde al delito de que se trate, lo que forma al final una progresión pluridimensional que reclama expresarse en la magnitud precisa de la pena. Por lo demás, intuitivamente, todo juez sabe que se encontrará con una progresión de este jaez, con elementos que denotan una mayor o menor antijuridicidad y otros que revelan una culpabilidad más o menos acentuada. La principal dificultad de la tarea será reducir la progresión pluridimensional a una serie unidimensional ${ }^{62}$, o como se dice en nuestro tiempo, convertir un juicio comparativo en un juicio métrico de valor.

Este era un hallazgo sobresaliente. Radbruch había encontrado el preciso punto de contacto, el puente que une las teorías de delito y pena. El lazo lo proporciona la conmensuración de la pena, siquiera sus bases yacen en los dos elementos mensurables del delito, la antijuridicidad y la culpabilidad. Toda la teoría de la «medición» de la pena presupone que el concepto del delito es un concepto graduable. Pero como la estimación de la gravedad objetiva y subjetiva del delito no opera en abstracto, sino siempre respecto de un caso definido, así también la pena tiene que ser graduada para el supuesto concreto, porque a falta de este paso la ejecución, cuyo objeto es una entidad bien precisa, tampoco podría tener lugar. En este sentido, la contribución de los conceptos ordenadores es reconocida hoy por los principales teóricos de la conmensuración de la pena ${ }^{63}$.

62. Ídem, cfr. pág. 208.

63. Bruns, Hans-Jürgen: Strafzumessungsrecht. Gesamtdarstellung, Carl Heymanns Verlag, Köln-Berlin-Bonn-München, 2ª ed., 1974, cfr. pág. 81, con cita de Radbruch.

Revista de Ciencias Sociales - Número 69 (2016) - Universidad de Valparáíso - ISSN 0716-7725-Valparaíso, Chile 


\section{Hacia la flexibilización del dualismo metodológico}

Desde su adscripción a la gnoseología neokantiana Radbruch abrazó el dualismo metodológico.

Basado en la distinción de realidad y valor, este dualismo postula que el estudio de los valores es independiente de la consideración de la realidad natural. Los juicios de valor no pueden fundamentarse inductivamente en el plano del ser, deben ser obtenidos de proposiciones de la misma índole, de otros juicios de valor ${ }^{64}$. La realidad como tal es siempre un dato de hecho carente de sentido, nada más que el imperio de la naturaleza. Sólo la conciencia que valora puede atribuir a las cosas un sentido valioso o disvalioso. Y como el hombre transforma la realidad por consideración a los fines hacia los que él aspira, resulta que la cultura es un dato de hecho que tiene el sentido de realizar valores. En este mundo se inscribe el Derecho, que es un fenómeno cultural, un dato de hecho que posee el sentido de realizar la idea del Derecho; y para comprenderlo, no sólo para juzgarlo o criticarlo, es indispensable tomar en cuenta los fines valorados que él encarna, los cuales vienen a ser determinantes para su interpretación. Así, el dualismo acaba en un trialismo en los modos de consideración del Derecho, al que cabe contemplar como un dato de hecho, un valor puro o un hecho referido a valores ${ }^{65}$. Por ejemplo, en el sector de los delitos y penas, la Criminología los mira como sucesos fácticos, la Filosofía jurídico-penal como puros conceptos valorativos y la Dogmática penal como realidades referidas a valores.

Sin embargo, es un error concluir que del contraste entre ser y deber ser, realidad empírica y significación normativa, el neokantismo jurídico habría radicalizado la separación de los mundos natural y jurídico ${ }^{66}$, con lo que habría preparado también las tendencias

64. RADBRUCH, Gustav: Filosofía del Derecho, ed. cit., pág. 14: "La consideración del valor y la consideración del ser, se nos aparecen una junto a la otra como círculos independientes y cerrados. Esta es la esencia del dualismo metodológico”.

65. Ídem, cfr. págs. 38 y 39.

66. La equivocación se remonta a Welzel, el mayor crítico de la filosofía de los valores en el Derecho penal, en su libro, por demás estupendo, Naturalismus

Facultad de Derecho y Ciencias Sociales - Universidad de Valparaíso - Chile 
normativistas de la doctrina penal de nuestros días, a las que, en efecto, sirve de inspiración una acusada autonomía, la impermeabilidad compacta del Derecho y su ciencia frente a los datos de naturaleza y sociedad. Para Emil Lask, en particular, Derecho y realidad prejurídica parecen estar enfrentados como dos reinos que nunca se tocan, como en la extremosa oposición que pretende la alienación constructivista. Lask se planteó como problema "la compenetración de la significación jurídica con el substrato real en el caso particular" y, yendo más allá, "la cuestión tan difícil del amoldamiento de los conceptos jurídicos al substrato prejurídico". Su conclusión fue que el Derecho tiene que respetar un cierto núcleo de lo dado en el plano psicofísico, en la medida que éste afecta al plano del pensamiento jurídico, y, por otra parte, "que las relaciones de vida ofrecen ya un material típicamente formado, preparado, por lo tanto, para la normación jurídica" ${ }^{{ }^{67}}$. Nada de lo cual puede valer como prueba de la exacerbación mencionada y, al contrario, certifica un normativismo sumamente atento a las informaciones procedentes del medio natural y social.

$\mathrm{Al}$ mismo enfoque responde la fórmula de la determinación material de la idea, que Radbruch, inspirado en Lask, presenta en 1923. Por cierto, el autor asume un punto de partida kantiano. La idea - por tanto, la forma y, con ella, el método de conocimiento- pretende reinar sobre la materia. Pero la adhesión al formalismo de Kant es sólo aparente, ya que de inmediato Radbruch advierte que la idea está materialmente determinada, vale por y para su materia. Esto quiere decir que, pese a su independencia gnoseológica, que le permite elaborar autónomamente sus conceptos, la Ciencia del Derecho tiene que asumir que todo deber ser lo es para una determinada materia, por cuyo motivo las formas que adopte quedan también prefiguradas por su materia prima. Aquí, en la delineación del molde de las instituciones y el curso

und Wertphilosophie, que citamos según la recopilación de obras del autor, Abhandlungen zum Strafrecht und zur Rechtsphilosophie, Walter de Gruyter, Berlin-New York, 1975, cfr. pág. 91.

67. LASK, Emil: Filosofía jurídica, Depalma, Buenos Aires, 1946. (prólogo de Enrique Martínez Paz y traducción de Roberto Goldschmidt). Págs. 74 y 83, respectivamente.

Revista de Ciencias Sociales - Número 69 (2016) - Universidad de Valparáíso - ISSN 0716-7725-Valparáiso, Chile 
ordenador del pensamiento jurídico, cobran tributación la época y la nación respectiva, las condiciones económicas y sociales de ésta, sus necesidades y aspiraciones valorativas, en una palabra, su cultura. Por eso apunta que "la Ciencia del Derecho presupone una preformación conceptual de su materia; no es producción conceptual primitiva, como las ciencias naturales, sino trabajo conceptual de segundo grado", y que "materia del Derecho es la circunstancia preformada mediante conceptos sociales" ${ }^{68}$.

Ahora bien, la determinación material de la idea es capaz de atenuar, pero no de suprimir el dualismo metódico. Materia del Derecho son hechos y circunstancias preformados categorialmente a través de conceptos sociales. Llevan, pues, una valoración preliminar que los convierte en realidad significativa, como el concepto del acto delictuoso y su estimación de primer grado de los penalistas neokantianos ${ }^{69}$. Sobre dichos conceptos se levantan los conceptos jurídicos condicionados, sin que por ello éstos pierdan la individualidad que les garantiza el mundo ideal de significados al que pertenecen. Y es que el artículo que comentamos persevera en la distinción entre realidad y valoración jurídica, pese a lo cual consigue moderar la rigidez de los extremos de la dicotomía. La aproximación de las formas puras del pensamiento jurídico a las materias primas sobre las que opera la regulación del Derecho sobreviene merced a la elaboración sociológica de éstas y a la reducción fenomenológica aportada por la doctrina de la «naturaleza de la cosa». Radbruch es muy escueto acerca de la última en el escrito de 1923. En cambio, un extenso trabajo de 1948, dedicado íntegramente a la naturaleza de la cosa como forma del pensamiento jurídico, reemprende la investigación iniciada un cuarto de siglo antes y la redondea con las mismas ideas de entonces. La naturaleza de la cosa no es el simple ser de los hechos o datos naturales, sino su esencia o

68. Idea y materia del Derecho, cit., págs. 40 y 42, el segundo pasaje, con cursivas en el original.

69. RADBRUCH: ídem, cfr. págs. 40-41, nombra como ejemplo la acción del delito de injurias, cuyo resultado no debe ser más ilustrado al modo naturalista de Liszt, como un efecto en el organismo interno del injuriado, sino que hay que asirlo como un suceso provisto de una significación social.

Facultad de Derecho y Ciencias Sociales - Universidad de Valparaíso - Chile 
sentido objetivo, un contenido de significados inmanente a la materia jurídica y que el Derecho no puede negar si desea poner manos en ella y manejarla conceptualmente. Para Radbruch, la naturaleza de la cosa, por más que no sea fuente de prescripciones jurídicas, sino un medio con que interpretar las existentes, representa una idea rectora para el legislador, porque está inscripta en la propia idea del Derecho. Carece de una función axiológica directa, ya que tampoco permite juzgar acerca de la corrección o incorrección de un ordenamiento jurídico, pero, como contrapartida, posibilita circunscribir el campo de lo ordenable jurídicamente y, por tanto, mantener a raya la voluntad del legislador, conjurar el temible despotismo legal ${ }^{70}$.

Radbruch dedicó los últimos meses de su vida a realizar una aplicación histórica de la determinación material de las formas jurídicas en un hermosísimo estudio de historia de la criminalidad. De nuevo el puente entre ser y deber ser es la cultura, el Derecho entendido como fenómeno cultural ${ }^{71}$. La historia del crimen es un fragmento de la historia de la cultura en general, aunque también una parte de la Criminología, cuyo segmento histórico investiga fenómenos criminales comunes a épocas pretéritas, "mostrando cómo el espíritu y las circunstancias de la época influyen sobre la criminalidad de un período determinado, para así llevar también a nuestro conocimiento, dentro de su estilo y límites, la condicionalidad histórica de la criminalidad actual"72. Sin embargo, a la vez la Criminología histórica ilustra por

70. RADBRUCH: La naturaleza de la cosa como forma jurídica del pensamiento, versión española, introducción y notas bibliográficas de Ernesto Garzón Valdés, Dirección General de Publicaciones de la Universidad Nacional de Córdoba, Córdoba (República Argentina), 1963, cfr. págs. 78 y 79. Véase, además, el logrado resumen de Engisch. En: Engisch, Karl: Gustav Radbruch como Filósofo del Derecho, en la Revista de Ciencias Sociales, Facultad de Ciencias Jurídicas, Económicas y Sociales, Universidad de Valparaíso, Edeval, Valparaíso, número 20 (monográfico: El neokantismo en la Filosofía del Derecho), primer semestre de 1982. (Trad. de Enrique Aimone Gibson) especialmente págs. 283-284.

71. Conforme, Köln, Michael Walter: “Gustav Radbruch y la Criminología”. En: Revista de Derecho penal y Criminología, de Buenos Aires, cit., año V, número 10, noviembre de 2015. (Trad. de Andrea Bartos) Pág. 107.

72. Radbruch y Gwinner: Historia de la criminalidad. (Ensayo de una Criminología histórica), notas y adiciones por Arturo Majada, Bosch, Barcelona, 1955, pág. 6.

Revista de Ciencias Sociales - Número 69 (2016) - Universidad de Valparáíso - ISSN 0716-7725-Valparaíso, Chile 
qué el Derecho penal del pasado calificó como delito ciertas conductas. Como "no parte de un concepto suprahistórico, «natural», del delito"73, sino de otro culturalmente condicionado, ella puede enseñarnos, a lo menos en parte, por qué las leyes penales fueron aplicadas de determinada manera. Radbruch ensayó este método con particular éxito al ilustrar la criminalidad de los salteadores de caminos y la falsificación de documentos y de moneda en las Edades Media y Moderna, así como la persecución implacable de la caza furtiva y, por último, el cambio de la consideración del infanticidio, delito clave de los esfuerzos reformadores del Derecho penal en el siglo XVIII. Desgraciadamente, la Ciencia del Derecho de antaño, con contadísimas excepciones, fue inmune a las condicionalidades de la fenomenología criminal, por lo que contribuyó a la inaudita severidad de la legislación punitiva. Un paradigma lo brinda el trato duro e incomprensivo de los Estados hacia los gitanos, población vagabunda que cometía para sobrevivir pequeños delitos de astucia y hurtos de bagatela, casi nunca delitos violentos y jamás emprendió grandes empresas criminales, completamente ajenas a su modo de $\operatorname{ser}^{74}$.

Pero entonces tampoco existía la Criminología como disciplina científica. Hoy sabemos que ella es también una ciencia de la cultura, sólo que indirectamente, al estar su objeto delimitado por el Derecho. Como en su fracción histórica, no existe una separación tajante entre la Criminología y la Dogmática, así como tampoco se da un corte neto entre naturaleza y cultura. En la Dogmática penalista los conocimientos criminológicos son indispensables para adentrarse en la realidad de los fenómenos regulados por el Derecho punitivo —el único antídoto contra el opio del conceptualismo jurídico- - para interpretar adecuadamente las disposiciones sobre el delito en general, los delitos en particular y sus correspondientes puniciones. Con mucha frecuencia no es posible averiguar el contenido de las reglas jurídico-penales sin echar mano de los conocimientos criminológicos. Falta todavía, empero, la formulación de una teoría general acerca del valor de éstos en la inteligencia

\footnotetext{
73. Ibídem.

74. Ídem, cfr. págs. 197 y 198.
}

Facultad de Derecho y Ciencias Sociales - Universidad de Valparaíso - Chile 
normativa de las leyes penales, una que sepa conjugar los métodos hermenéuticos tradicionales con la metodología criminológica, basada en la observación y el experimento. Probablemente, la vía de acceso de la Criminología a la función interpretativa de la Ciencia del Derecho esté en el método teleológico que ésta utiliza.

Es posible que Radbruch, de haber alcanzado a proyectar sus estudios de Criminología histórica hacia la fenomenología contemporánea del delito, hubiera estado de acuerdo con ello.

\section{Conclusión}

Hemos llegado al final de nuestro repaso de la obra criminalista de Gustav Radbruch, con el que creemos corroborado que la significación de este autor para el Derecho penal contemporáneo se manifiesta en dos planos, uno histórico y otro actual.

Antes de abrazar la especial metodología teleológica del neokantismo sudoccidental, Radbruch culminó una valiosa depuración de los conceptos de acción, omisión, culpabilidad e imputabilidad. Sus logros con el sistema deductivo-clasificatorio continuaron los avances realizados por Merkel, Binding y Liszt, proseguirían en la obra de Beling y, por cierto, sostienen todavía la estructura de una doctrina jurídica del delito no degradada a mera teoría de la imputación penal. Por lo demás, el sistema en palabra está lejos de haber desaparecido de la Ciencia jurídica, como lo revela el esclarecimiento semántico que defienden los partidarios del neopositivismo y su refinado análisis de los términos que se emplea en la estructura de la infracción delictuosa.

Sin embargo, la vigencia de Radbruch parece más ligada a su concepción del Derecho como una realidad referida a valores. La Jurisprudencia valorativa no constituye un equivalente, sino una metodología distinta de la Jurisprudencia teleológica que encabezó Jhering y Liszt encarnó en el Derecho penal. Las valoraciones jurídicas tampoco son simples causas psicológicas de las leyes. Tienen sus pies apoyados en el terreno de la realidad individual y social, el reino de la naturaleza, pero reciben su sentido de aspiraciones más elevadas, del reino de los valores, el mismo que procuran imprimir a ese producto cultural — por decirlo con una metáfora grata a Radbruch, pero que se 
remonta a Pico della Mirandola — situado entre el polvo y las estrellas que es el Derecho. De intuiciones primero, del decidido desarrollo de la metodología de Baden después, provienen el vislumbre de la imputación objetiva del resultado, la posición sistemática de la imputabilidad, el lugar que toca al deber objetivo de cuidado en los delitos culposos, el concepto de autor por convicción y la aproximación de la Dogmática penal a la Criminología.

Hemos dejado deliberadamente al margen de nuestra reseña los trabajos de Política criminal, Derecho penitenciario y proceso penal que compuso Radbruch, al igual que su estudio de algunos delitos, especialmente la alta traición, que se corresponde aproximadamente con las figuras de rebelión y sedición de la tradición hispano-americana. No nos pareció indispensable incluirlos para el efecto de mostrar y demostrar el valor presente de esta figura humana en el saber penal, valor debido a una inteligencia excepcional, a su formación filosófica, constancia, despliegue poliédrico de la tensión intelectual, dignidad política, humanismo y, mas no en último lugar, sensibilidad artística. Conjeturamos que Radbruch se hubiera dolido de la bibliografía jurídico-penal de nuestro tiempo, ayuna de la extraordinaria belleza expresiva de sus escritos, a los que con razón se ha considerado como perlas de la bibliografía jurídica, algunas de las cuales podrían lucir con buenos títulos junto a lo más granado de la literatura en lengua alemana ${ }^{75}$. Es un mal signo de esta época, una de cuyas características es la producción estereotipada o en serie, que tal prenda haya dejado de merecer la estimación del público, incluso el especializado, en lo que se olvida que en la elegancia literaria hay claridad, en la claridad, belleza, y en la belleza, un poso de verdad.

\section{Bibliografía}

BARATTA, Alessandro: Relativismus und Naturrecht im Denken Gustav Radbruchs, en ídem, Philosophie und Strafrecht. Aufgewählte

75. De esta opinión, Schmidt, Eberhard: Gustav Radbruch als Kriminalist, cit., cfr. pág. 164. De hecho, sabemos que el estilo literario de Radbruch mereció el elogio nada menos que de Thomas Mann.

Facultad de Derecho y Ciencias Sociales - Universidad de Valparaíso - Chile 
Aufsätze 1959-1974. Carl Heymanns Verlag, Köln-Berlin-BonnMünchen, 1985, págs. 1-29.

BRUNS, Hans-Jürgen: Strafzumessungsrecht. Gesamtdarstellung, Carl Heymanns Verlag, Köln-Berlin-Bonn-München, $2^{\text {a }}$ ed., 1974.

CORCOY BIDASOLO, Mirentxu: El delito imprudente. Criterios de imputación del resultado, Editorial B. de F., Montevideo-Buenos Aires, 2005.

ENGELHARD, Herbert: Einführung in das Strafrecht an Hand von Rechtsfällen. Ergänzt und herausgegeben von G. Radbruch, Rausch, Heidelberg, $2^{\mathrm{a}}$ ed., 1948.

ENGISCH, Karl: Gustav Radbruch como Filósofo del Derecho, traducción de Enrique Aimone Gibson, en la Revista de Ciencias Sociales, Facultad de Ciencias Jurídicas, Económicas y Sociales, Universidad de Valparaíso, Edeval, Valparaíso, número 20 (monográfico: El neokantismo en la Filosofía del Derecho), primer semestre de 1982, págs. 275-285.

FERRI, Enrico: Proyecto preliminar de Código penal para Italia, traducción y estudio por Cristino Jiménez Escribano, epílogo de Quintiliano Saldaña, Centro Editorial de Góngora, Madrid, 1925. Jorge Frías Caballero, Capacidad de culpabilidad penal, Hammurabi, Buenos Aires, 1994.

FROMMEL, Monika: Einleitung, en Gustav Radbruch, Gesamtausgabe, herausgegeben von Arthur Kaufmann, 20 vols., C. F. Müller Verlag, Heidelberg, t. VII, 1995, págs. 1-4.

GUZMÁN DALBORA, José Luis: Derecho penal y minorías étnicas: planteamiento y liquidación criminalista de un problema político, en la Revista de Derecho penal y Criminología, de Buenos Aires, La Ley, año III, número 7, agosto de 2013, págs. 243-257, incluido también en el volumen Derecho penal y Constitución, compilado por Fernando Velásquez Velásquez y Renato Vargas Lozano, Universidad Sergio Arboleda, Bogotá, 2014, págs. 131-155.

GUZMÁN DALBORA, José Luis: El terrorismo como delito común, en el volumen Terrorismo y Derecho penal, editado por Kai Ambos, Ezequiel Malarino y Christian Steiner, Konrad-Adenauer-Stiftung, Montevideo, 2015, págs. 401-437.

GUZMÁN DALBORA, José Luis y FERNÁNDEZ, Gonzalo D.: «Estudio introductorio» de Gustav Radbruch, El concepto de

Revista de Ciencias Sociales - Número 69 (2016) - Universidad de Valparáíso - ISSN 0716-7725-Valparaíso, Chile 
acción y su importancia para el sistema del Derecho penal, traducción y notas de José Luis Guzmán Dalbora, Editorial B. de F., MontevideoBuenos Aires, 2011, págs. 1-42.

GUZMÁN DALBORA, José Luis: Estudio preliminar a la obra de Karl Engisch, La teoría de la libertad de la voluntad en la actual doctrina filosófica del Derecho penal. Editorial B. de F., Montevideo-Buenos Aires, 2006, págs. 13-15, publicado también por Edeval (colección «Juristas perennes», número 11), Valparaíso, 2006, págs. 15-50.

HIRSCH, Hans Joachim: Derecho penal y autor por convicción, traducción de Patricia Laurenzo Copello, en sus Obras completas, 5 vols., Rubinzal-Culzoni Editores, Buenos Aires, t. II, 2000, págs. 171-207.

JESCHECK, Hans-Heinrich: Gustav Radbruchs Beitrag zur Strafrechtsvergleichung, en Gedächtnisschrift für Gustav Radbruch, herausgegeben von Arthur Kaufmann, Vandenhoeck \& Ruprecht, Göttingen, 1968, págs. 356-365.

JESCHECK, Hans-Heinrich y WEIGEND, Thomas: Lehrbuch des Strafrechts. Allgemeiner Teil, Duncker \& Humblot, Berlín, 5a ed., 1996.

JIMÉNEZ DE ASÚA, Luis: Tratado de Derecho penal, publicados, 7 vols., Losada, Buenos Aires, 1ª ed., t. III, 1958, y t. V, 1956.

KAUFMANN, Arthur: Einleitung, en Gustav Radbruch, Gesamtausgabe, cit., t. VIII, 1988, págs. 1-11.

KAUFMANN, Arthur, y HASSEMER, Winfried: Einführung in Rechtsphilosophie und Rechtstheorie der Gegenwart, C. F. Müller Juristischer Verlag, Heidelberg, 6a ed., 1994.

KLEINHEYER, Gerd y SCHRÖDER, Jan: Deutsche und Europäische Juristen aus neun Jahrhunderten, C. F. Müller Verlag, Heidelberg, $4^{\mathrm{a}}$ ed., 1996.

KÖLN, Michael Walter: Gustav Radbruch y la Criminología, traducción de Andrea Bartos, en la Revista de Derecho penal y Criminología, de Buenos Aires, cit., año V, número 10, noviembre de 2015, págs. $103-$ 114.

LASK, Emil: Filosofía jurídica, prólogo de Enrique Martínez Paz y traducción de Roberto Goldschmidt, Depalma, Buenos Aires, 1946

Facultad de Derecho y Ciencias Sociales - Universidad de Valparaíso - Chile 
FRANZ VON LISZT, Tratado de Derecho penal, 3 vols., traducción de Luis Jiménez de Asúa y adiciones por Quintiliano Saldaña, Reus, Madrid, 1916.

MARTÍNEZ BRETONES, María Virginia: Gustav Radbruch. Vida y obra, Universidad Nacional Autónoma de México, México, $2^{\text {a }}$ ed., 2003.

MEZGER, Edmund: Tratado de Derecho penal, 2 vols., nueva edición, revisada y puesta al día por José Arturo Rodríguez Muñoz, Editorial Revista de Derecho Privado, Madrid, 1955.

MÜLLER, Max Ludwig: La significación de la relación causal en el Derecho penal y en el de reparación de daños, traducción de Marcelo A. Sancinetti, en el volumen compilado por éste Causalidad, riesgo $e$ imputación. 100 años de contribuciones críticas sobre imputación objetiva, Hammurabi, Buenos Aires, 2009, págs. 39-104.

OTTE, Holger: Gustav Radbruchs Kieler Jahre 1919-1926, Peter Lang, Frankfurt am Main-Bern, 1982.

RADBRUCH, Gustav: De la pena de muerte, traducción de José Luis Guzmán Dalbora, en la Revista de Derecho Penal y Criminología, de Buenos Aires, cit., año IV, número 1, febrero de 2014, pág. 252.

RADBRUCH, Gustav: Die Lehre von der adäquaten Verursachung, Abhandlungen des Kriminalistischen Instituts an der Universität Berlin, Nueva serie, número 3, Berlín, 1902, incluida en Gesamtausgabe, cit., t. VII, cit., págs. 7-74.

RADBRUCH, Gustav: Der innere Weg. Aufriss meines Lebens, K.F. Verlag, Stuttgart, 1951.

RADBRUCH, Gustav: Der Überzeugungsverbrecher, en Gesamtausgabe, cit., t. VIII, cit., págs. 131-133.

RADBRUCH, Gustav: Die gesetzliche Strafänderung, en Vergleichende Darstellung des deutschen und ausländischen Strafrechts, Allgemeiner Teil, 6 vols., Liebmann, Berlin, t. II, 1908, págs. 189-219. RADBRUCH, Gustav: Drei Strafrechtslehrbücher des 19. Jahrhunderts, en Arthur Wegner (editor), Festschrift für Ernst Heinrich Rosenfeld zu seinem 80. Geburtstag am 14. August 1949, Walter de Gruyter, Berlin, 1949, págs. 7-28.

RADBRUCH, Gustav: Conceptos de clasificación y conceptos ordenadores en el pensamiento jurídico, en ídem, El concepto de acción y su importancia para el sistema del Derecho penal, cit., págs. 199-214.

Revista de Ciencias Sociales - Número 69 (2016) - Universidad de Valparáíso - ISSN 0716-7725-Valparaíso, Chile 
RADBRUCH, Gustav: Elegantiae Juris Criminalis, Verlag für Recht und Gesellschaft AG., Basel, 2a ed., 1950.

RADBRUCH, Gustav: El delincuente por convicción, traducción y notas de José Luis Guzmán Dalbora, en la Revista Electrónica de Ciencia penal y Criminología, de Granada (España), 2005, número 7, disponible en internet http://criminet.ugr.es/recpc/07/repc07-r4.pdf.

RADBRUCH, Gustav: El relativismo en la Filosofía del Derecho, en ídem, El hombre en el Derecho. Conferencias y artículos seleccionados sobre cuestiones fundamentales del Derecho, traducción de Aníbal del Campo, Depalma, Buenos Aires, 1980, págs. 95-102.

RADBRUCH, Gustav: Erfolgshaftung, en Vergleichende Darstellung des deutschen und ausländischen Strafrechts, Allgemeiner Teil, cit., t. III, 1908, págs. 227-253.

RADBRUCH, Gustav: Filosofía del Derecho, traducción de José Medina Echavarría, Editorial Revista de Derecho Privado, Madrid, $3^{a}$ ed., 1952.

RADBRUCH, Gustav: Idea y materia del Derecho. Un esbozo, en ídem, Tres estudios de Filosofía del Derecho y una arenga para los jóvenes juristas, traducción, introducción y notas por José Luis Guzmán Dalbora, Editorial B. de F., Montevideo-Buenos Aires, 2013, págs. 33-45.

RADBRUCH, Gustav: La idea educativa en el Derecho penal, en El hombre en el Derecho, cit., págs. 61-74.

RADBRUCH, Gustav: La naturaleza de la cosa como forma jurídica del pensamiento, versión española, introducción y notas bibliográficas de Ernesto Garzón Valdés, Dirección General de Publicaciones de la Universidad Nacional de Córdoba, Córdoba (República Argentina), 1963.

RADBRUCH, Gustav: Sobre el sistema de la teoría del delito, en ídem, El concepto de acción y su importancia para el sistema del Derecho penal, cit., págs. 177-197.

RADBRUCH, Gustav: Über den Schuldbegriff, en Gesamtausgabe, cit., t. VII, cit., págs. 207-219.

RADBRUCH, Gustav: Über die Frage vom Überzeugungsverbrecher, en Gesamtausgabe, cit., t. VIII, cit., págs. 134-189.

RADBRUCH, Gustav: Zur Psycologie der strafrechlichen Schuldformen, en Gesamtausgabe, cit., t. VIII, cit., págs. 184-189.

Facultad de Derecho y Ciencias Sociales - Universidad de Valparaíso - Chile 
RADBRUCH, Gustav, y GWINNER, Enrique: Historia de la criminalidad. (Ensayo de una Criminología histórica), notas y adiciones por Arturo Majada, Bosch, Barcelona, 1955; Marcelino Rodríguez Molinero, Gustavo Radbruch, penalista, en Nieto Martín (coordinador), Homenaje al Dr. Marino Barbero Santos. "In memoriam», 2 vols., Ediciones de la Universidad de Castilla-La Mancha y Salamanca, Cuenca, 2001, t. I, págs. 579-593.

ROXIN, Claus: Derecho penal. Parte general, tomo I, Fundamentos. La estructura jurídica del delito, traducción de la $2^{\mathrm{a}}$ edición alemana por Diego-Manuel Luzón Peña, Miguel Díaz y García Conlledo, y Javier de Vicente Remesal, Cívitas, Madrid, 1997.

SCHMIDHÄUSER, Eberhard: Sobre la sistemática de la teoría del delito. Un tema fundamental de Radbruch desde el punto de vista de la nueva dogmática penal, traducción de Juan Bustos Ramírez, en la revista Nuevo pensamiento penal, de Buenos Aires, año 4, enero-marzo de 1975, número 5, págs. 33-46.

SCHMIDT, Eberhard: Einführung in die Geschichte der deutschen Strafrechtspflege, Vandenhoeck \& Ruprecht, Göttingen, $3^{\mathrm{a}}$ ed., 1995.

SCHMIDT, Eberhard: Gustav Radbruch als Kriminalist, en Zeitschrift für die gesamte Strafrechtswissenschaft, Walter de Gruyter \& Co., Berlín, tomo 63, 1951, págs. 150-165.

WEITZ, Eric. D.: La Alemania de Weimar. Presagio y tragedia, traducción de Gregorio Cantera, Turner, Madrid, 2009.

WELZEL Hans: Naturalismus und Wertphilosophie, en ídem, Abhandlungen zum Strafrecht und zur Rechtsphilosophie, Walter de Gruyter, Berlin-New York, 1975, págs. 29-119. 